формування чітких особистісних цілей, раціонального використання свого часу, кваліфікованого опрацювання та використання інформації.

У процесі розвитку у студентів почуття професійної гідності, відповідальності та компетентності у розв'язанні професійних задач велику роль відіграє можливість активної участі у створенні програми власного професійного розвитку, прийнятті рішень, які стосуються власної освіти, організації навчальної та науково-дослідницької діяльності. Водночас із розв'язанням навчальних проблем майбутній фахівець повинен мати змогу акцентувати власні зусилля на саморозвиток та самоствердження, вдосконалення професійних здібностей, становлення професійної самосвідомості [3, с. 7].

Організація навчального процесу у вищій школі покликана сприяти постійному перетворенню особистісно-суспільних цілей у дієвий внутрішній стимул професійного становлення студентів, закріплення та розвиток активної професійної позиції і творчого стилю діяльності [ 3, с. 8].

У кожної людини є нереалізований потенціал. Безумовно, наявні межі індивідуальних можливостей: вік, здоров'я, сімейна ситуація, освіта тощо. Але якщо людина спробує хоча б частково подолати ці обмеження, які заважають ії розвитку, то можна переконатися, що багато 3 них лише здаються незборимими. Як казав В. Джеймс, «серед усіх створінь, які живуть на Землі, лише людина може змінити себе» [4, с. 10].

Отже, актуальною проблемою сьогодення є формування творчої та високо професійної особистості вчителя, який вміє керувати собою за будь-яких обставин. Результати проведеного опитування серед студентів педагогічного інституту зумовлюють необхідність формування в майбутніх учителів грунтовних знань та умінь самоуправління.

Лiтература
1. Завадський Й. С. Менеджмент: Management / Й. С. Завадський - К. : Українсько-фінський інститут менеджменту і бізнесу, 1997. - 543 с. 2. Зайверт Л. Ваше время - в ваших руках:[ пер. с нем.] / Л. Зайверт. - М. : Экономика, 1991. - 125 с. З. Кондрашова Л. В. Формування професійного «я» майбутніх педагогів засобами особистісно зорієнтованого навчання в практиці вищої школи / Л. В. Кондрашова // Педагогіка вищої та середньої школи. - Кривий Ріг, 2000. - Вип. 2. - С. 3-13. 4. Крыжко В. В. Психология в практике менеджера образования /
В. В. Крыжко, Е. М. Павлютенков. - СПб. : КАРО, 2002. - 304 с. 5. Латыпова М. Школьный менеджмент: модное слово или путь к совершенствованию? / М. Латыпова // Народное образование. - 2000. - № 1. - С. 76 83. 6. Лукашевич М. П. Теорія і практика самоменеджменту: [навч. посіб.] / М. П. Лукашевич. - К. : МАУП, 1999. - 360 с. 7. Оглоблин В. Персональный менеджмент - основа успешной карьеры // Управление персоналом. - 2004. - №14. - С. 5-8. 8. Рибалкін В. О. Основи економічної теорії: [посіб. для студ. вищ. навч. закл.] / В. О. Рибалкін, М. О. Хмелевський, Т. І. Біленко. - К. : ВЦ «Академія», 2002. - 352 с. 9. Штельмах Г. Б. Принцип гуманізації та психологізації педагогічного менеджменту як основа реалізації особистісно-орієнтованого навчання під час процесу професійної перепідготовки педагогічних кадрів / Г. Б. Штельмах, О. Б. Поліщук // Педагогіка вищої та середньої школи. - Кривий Ріг, 2004, - Вип. 7. - С. 92-96.

УДК 378.147

Вероніка Сгорова

\title{
ІНФОРМАЦЙНО-ТЕХНОЛОГІЧНА КЛЮЧОВА КОМПЕТЕНТНІСТЬ ВИКЛАДАЧІВ ІНОЗЕМНИХ МОВ ВНЗ ЯК НЕОБХІДНА УМОВА ЇХНЬОГО ПРОФЕСІЙНОГО РОЗВИТКУ
}

Єгорова В. В. Інформаційно-технологічна ключова компетентність викладачів іноземних мов ВНЗ як необхідна умова їхнього професійного розвитку.

Статтю присвячено аналізу й обгрунтуванню складників інформаційно-технологічної ключової компетентності викладачів іноземних мов ВН3 та ії характеристик, практичному впровадженню результатів теоретичного дослідження.

Ключові слова: ключові компетентності, інформаційно-технологічна ключова компетентність, викладачі іноземних мов ВНЗ, науково-педагогічні працівники.

Егорова В. В. Информационно-технологическая ключевая компетентность преподавателей иностранных языков вузов как необходимое условие их профессионального развития.

Статья посвящена анализу и обоснованию составляющих информационно-технологической 
ключевой компетентности преподавателей иностранных языков вузов и ее характеристик, практическому применению результатов теоретического исследования.

Ключевые слова: ключевые компетентности, информационно-технологическая ключевая компетентность, преподаватели иностранных языков вузов, научно-педагогические работники.

Egorova V. V. Information technology a key competence of teachers of foreign languages schools as a necessary condition for their professional development.

The article is dedicated to the analysis and argumentations the components and characteristics of the informational-technological key competence of teachers of the institutes of higher education, practical application is added.

Key words: key competences, informational-technological key competence, teachers of foreign languages, teachers of the institutes of higher education.

Пріоритетна увага в реформуванні вищої освіти в Україні надається підготовці нового покоління науково-педагогічних кадрів, національній еліті, яка буде спроможна реалізувати нову освітньо-світоглядну парадигму національного та державного творення. За нашим переконанням, викладачу ВНЗ потрібно оволодіти низкою ключових компетентностей, щоб здійснювати професійну діяльність. Розвиток зазначених ключових компетентностей науковопедагогічних працівників сприятиме їх професійному зростанню та конкурентоздатності викладачів ВНЗ на сучасному ринку праці.

Аналіз психологічних, педагогічних та методичних наукових робіт свідчить про значний інтерес вітчизняних та зарубіжних дослідників до визначення змісту поняття та складників ключових компетентностей (Г. Сльникова, І. Зимня, О. Овчарук, О. Пометун, Л. Хоружа, А. Хуторський та ін.). Неперервна освіта $\epsilon$ важливим елементом у формуванні та розвитку нового підходу щодо становлення вищої школи України, але незначна кількість науковців наголошує на важливості розвитку ключових компетентностей науково-педагогічних працівників у системі методичної роботи ВНЗ на основі компетентнісного підходу.

Meта статті - розкрити складники та характеристики інформаційно-технологічної ключової компетентності для науково-педагогічних працівників (на прикладі викладачів іноземних мов).

На нашу думку, ключові компетентності складають інваріантну частину професійної компетентності науково-педагогічного працівника, що охоплює систему певних знань, умінь, навичок та емоційно-цінністе ставлення, необхідних для здійснення науково-педагогічної діяльності. Ключові компетентності викладача ВНЗ є універсальними, вони забезпечують продуктивну педагогічну діяльність загалом.

Узагальнюючи теоретичні положення різних авторів та аналізуючи практичний досвід провідних викладачів низки університетів, нами визначено сучасні ключові компетентності науково-педагогічних працівників ВНЗ як комплекс постійно збагачуваних особистісних якостей (характеристик) науково-педагогічного працівника, що забезпечує якісне та ефективне виконання професійної діяльності, сприяє самовдосконаленню та підвищенню рівня педагогічної майстерності, до якого належать: фахова, соціально-психологічна, інформаційнотехнологічна, соціально-педагогічна та загальнокультурна.

Інформаційно-технологічна ключова компетентність охоплює компетентності в галузі інформаційно-комунікаційних технологій зокрема та сучасних педагогічних технологій загалом (знання про технології та знання технологій, методів, засобів, форм діяльності та умов їхнього застосування тощо), передбачає здатність орієнтуватися в інформаційному просторі, володіти та оперувати інформацією відповідно до потреб ринку праці. Ми розмежовуємо такі складники зазначеної компетентності (згідно 3 наказом $\mathrm{MOH}$ України № 450 [1] та «Кваліфікаційних вимог до професійної діяльності педагогічних працівників» [2]), які мають свої певні характеристики: загального користування (характеризується постійним оновленням) та спеціально-педагогічний (стабільніший) [3, с. 83] (Табл.1).

Великий практичний досвід, накопичений в Україні й за кордоном, доводить, що сучасні педагогічні технології сприяють інтенсифікації та оптимізації навчального процесу у вищій школі. Вони допомагають тим, хто навчається, аналізувати навчальну інформацію, творчо підходити до засвоєння навчального матеріалу i, отже, зробити засвоєння знань більш доступним; навчитися формулювати власну думку, правильно іiї висловлювати, доводити 
власну позицію, аргументувати й дискутувати; навчитися слухати іншу людину, поважати альтернативну думку; моделювати різні соціальні та професійні ситуації, збагачувати власний досвід через включення в ці життєві ситуації; вчитися будувати конструктивні стосунки в колективі, визначати своє місце в ньому, вміти уникати конфліктів, розв'язувати їх та шукати компроміси; розвивати навички проектної діяльності, самостійної роботи, виконання творчих завдань тощо.

Таблиия 1

Інформаційно-технологічна ключова компетентність науково-педагогічного працівника (на прикладі викладачів іноземних мов ВНЗ)

\begin{tabular}{|c|c|c|c|}
\hline \multirow{2}{*}{$\begin{array}{c}\text { Ключова } \\
\text { компе- } \\
\text { тентність }\end{array}$} & \multirow{2}{*}{$\begin{array}{c}\text { Склад- } \\
\text { ники }\end{array}$} & \multicolumn{2}{|l|}{ Характеристики } \\
\hline & & ЗУН & $\begin{array}{c}\text { Емоційно-ціннісне } \\
\text { ставлення }\end{array}$ \\
\hline \multirow[b]{2}{*}{ 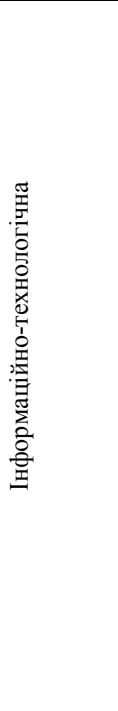 } & 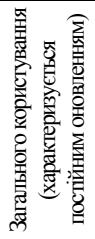 & $\begin{array}{l}\text { 3нання про: комп'ютер, обладнання та прикладне програмне } \\
\text { забезпечення на рівні користувача; уміння користуватись } \\
\text { комунікаційними засобами (Інтернет, електронна пошта } \\
\text { тощо), мати уявлення про різноманітні медіаресурси та вміти } \\
\text { користуватися ними; знання санітарних норм при роботі } 3 \\
\text { комп’ютером та обладнанням; про сучасні педагогічні } \\
\text { технології; про нормативно-правові аспекти використання } \\
\text { комп'ютерних освітніх ресурсів. }\end{array}$ & \multirow{2}{*}{$\begin{array}{l}\text { Пов’язане із: } \\
\text { виконанням } \\
\text { санітарних норм } \\
\text { при роботі з } \\
\text { комп'ютером та } \\
\text { обладнанням; } \\
\text { усвідомленням } \\
\text { правових аспектів } \\
\text { використання } \\
\text { комп'ютерних } \\
\text { ресурсів; ільності } \\
\text { використання IКТ } \\
\text { та сучасних } \\
\text { педагогічних } \\
\text { технологій }\end{array}$} \\
\hline & 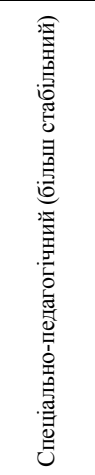 & 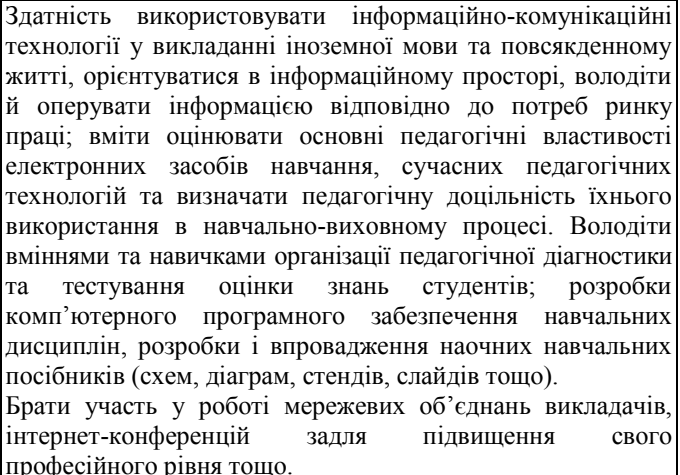 & \\
\hline
\end{tabular}

Крім того, використання сучасних педагогічних технологій дозволяє реалізувати ідею співробітництва тих, хто навчає, і тих, хто навчається, учить їх конструктивній взаємодії, сприяє створенню позитивного психологічного клімату на занятті, створює доброзичливу атмосферу. Як зазначає О. Падалка, використання IКТ «пов'язане передовсім із вмінням студентів та викладачів послуговуватися такими сучасними носіями інформації, як комп'ютер, а також із вмінням викладачів навчити студентів систематизувати та оцінювати хаотичний потік інформації, який надходить до них з Інтернету та інших сучасних джерел інформації» [4, c. 94-95]. Питання застосування зазначених технологій є очевидним. Це стосується не лише нових технічних засобів, але й нових форм і методів викладання. Небайдужий до своєї науково-педагогічної діяльності викладач ВНЗ перебуває в постійному творчому пошуку, враховуючи вимоги сьогодення, що, відповідно, актуалізує питання щодо вмінь та навичок використання безмежних можливостей ІКТ. Ми вважаємо, що кожен викладач повинен оволодіти достатнім рівнем комп'ютерної грамотності та сучасної інформаційної культури, оскільки частина викладачів ВНЗ не володіє початковими навичками користування IКТ та не може подолати психологічний бар'єр щодо їхнього застосування.

Зазначена проблема потребує нагального розв'язання, оскільки безпосереднє використання інформаційно-комунікаційних технологій спрощує викладання низки дисциплін та контроль знань, що, у свою чергу, безпосередньо стосується навчання іноземних мов. Маємо додати, що за допомогою комп'ютера також легше проводити індивідуальне навчання (як приклад, практика використання дистанційного навчання; самостійна робота студентів). 
Ураховуючи зазначене вище, ми переконані, що мінімальний рівень інформаційної культури сучасних науково-педагогічних працівників має складатися із знання та володіння такими засобами:

- комп'ютерними операційними системами (Windows, UNIX, Linux тощо), які $є$ необхідними для роботи з різними файлами;

- текстовими процесорами та редакторами: Word perfect, MS Word, Microsoft Power Point тощо. Вміння користуватись останніми дозволяє видавати індивідуальні завдання, сприяє розвитку творчості як студентів, так і викладачів вищого навчального закладу;

- системами навігації в мережі Internet, які сприяють спрощенню пошуку потрібного матеріалу.

Отже, можна сказати, що «ІКТ-компетентність» - властивість педагога, який компетентно, тобто цілеспрямовано і самостійно, із знанням вимог до професійної діяльності в умовах інформатизації освітнього простору і своїх можливостей та обмежень здатний застосовувати IКТ у процесі навчання, виховання, методичної і дослідницької діяльності та власної неперервної професійної педагогічної діяльності, на основі аналізу педагогічних ситуацій може бачити і формулювати педагогічні завдання та знаходити оптимальні способи їх розв'язання із максимальним використанням можливостей IКТ» [5, с. 45].

Успішний розвиток процесів інформатизації вищої освіти безпосередньо залежить від професійного розвитку науково-педагогічних кадрів. Нині для розв'язання цього завдання все ширше починає використовуватися Інтернет. 3'являється все більше можливостей щодо використання сучасних мережевих технологій для поточної підтримки викладачів вищого навчального закладу в професійній діяльності. Нові інформаційно-комунікаційні технології в навчанні й вихованні використовуються, але не надто широко. Причинами є як недостатнє забезпечення комп’ютерною технікою, так і ІКТ-некомпетентність користувачів.

3 урахуванням названих умов нами розроблено й апробовано рівні та характеристики для оцінювання інформаційно-технологічної ключової компетентності науково-педагогічного працівника (на прикладі викладачів іноземних мов ВНЗ). Табл. 2 [3, с. 249-250].

Таблиия 2

Оцінювання рівня інформаційно-технологічної ключової компетентності науково-педагогічного працівника

\begin{tabular}{|c|c|c|}
\hline Рівень & Якісна характеристика & $\%$ \\
\hline 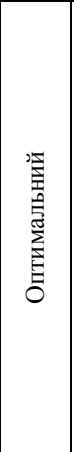 & $\begin{array}{l}\text { Викладач має достатні знання про комп'ютер, обладнання та прикладне програмне } \\
\text { забезпечення на рівні користувача; уміє користуватися комунікаційними засобами (Інтернет, } \\
\text { електронна пошта тощо); має уявлення про різноманітні медіаресурси та вміє користуватись } \\
\text { ними; знає та виконує санітарні норми під час роботи з комп'ютером та обладнанням; володіє } \\
\text { знаннями про нормативно-правові аспекти використання комп'ютерних освітніх ресурсів. } \\
\text { Викладач здатний використовувати інформаційно-комунікаційні технології, сучасні педагогічні } \\
\text { технології у викладанні навчального предмета, добре орієнтується в інформаційному } \\
\text { просторі, володіє й оперує інформацією відповідно до потреб ринку праці; вміє оцінювати } \\
\text { основні педагогічні властивості електронних засобів навчання, сучасних педагогічних } \\
\text { технологій та визначати педагогічну доцільність їнього використання в навчально- } \\
\text { виховному процесі. Володіє вміннями та навичками організації педагогічної діагностики та } \\
\text { тестування оцінки знань студентів; розроблення комп'ютерного програмного забезпечення } \\
\text { навчальних дисциплін, розроблення і впровадження наочних навчальних посібників (схем, } \\
\text { діаграм, стендів, слайдів тощо). Бере участь у роботі мережевих об'єднань викладачів, } \\
\text { інтернет-конференціях задля підвищення свого професійного рівня тощо. }\end{array}$ & $\frac{8}{8}$ \\
\hline 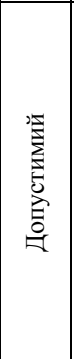 & $\begin{array}{l}\text { Викладач має знання про комп’ютер, обладнання та прикладне програмне забезпечення на } \\
\text { рівні користувача; уміє користуватися комунікаційними засобами (Інтернет, електронна } \\
\text { пошта тощо); має уявлення про різноманітні медіаресурси та вміє користуватися ними; знає } \\
\text { та виконує санітарні норми при роботі з комп’ютером та обладнанням; володіє знаннями } \\
\text { про нормативно-правові аспекти використання комп'ютерних освітніх ресурсів. Викладач } \\
\text { здатний використовувати інформаційно-комунікаційні технології, сучасні педагогічні } \\
\text { технології у викладанні навчального предмета, але не завжди це використовує у своїй } \\
\text { діяльності; орієнтуєься в інформаційному просторі, володіє інформацією відповідно до } \\
\text { потреб ринку праці; вміє оцінювати основні педагогічні властивості сучасних педагогічних } \\
\text { технологій. Володіє вміннями та навиками організації педагогічної діагностики та } \\
\text { тестування оцінки знань студентів; розроблення комп’ютерного програмного забезпечення } \\
\text { навчальних дисциплін. }\end{array}$ & के \\
\hline
\end{tabular}




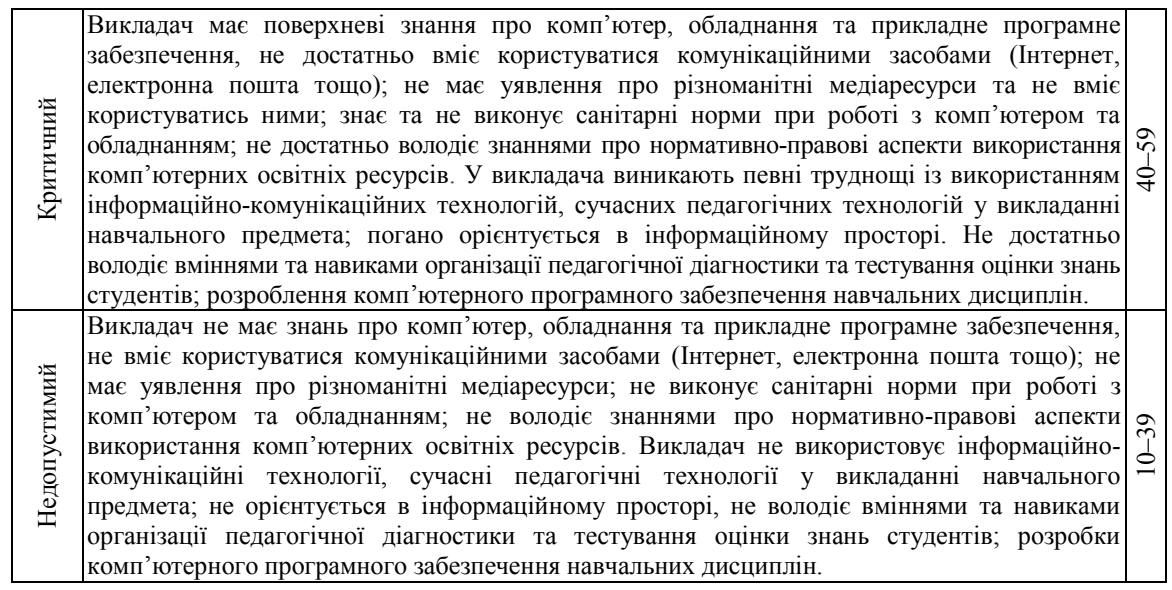

Беззаперечною метою впровадження інформаційно-комунікаційних технологій $\epsilon$ формування в особистості сучасної інформаційної культури, тобто володіння навичками роботи 3 електронними, цифровими засобами. Така людина $\epsilon$ підготовленою до життя в інформаційному суспільстві. Ми наголошуємо на тому, що науково-педагогічним працівникам взагалі, а викладачам іноземних мов ВНЗ зокрема, необхідно звертати постійну увагу на нові технології роботи з інформацією та розвиток комп'ютерної техніки, щоб бути обізнаним, компетентним у зазначеній сфері. Перспективу подальшого дослідження ми вбачаємо в розробленні тренінгів для розвитку зазначеної нами ключової компетентності.

\section{Література}

1. Про затвердження норм часу для планування і обліку навчальної роботи та переліків основних видів методичної, наукової й організаційної роботи педагогічних і науково-педагогічних працівників вищих навчальних закладів : наказ М-ва освіти і науки України № 450 від 07.08.02 p. // Інформ. зб. М-ва освіти і науки України. - 2002. - № 22. - С. 3-11. 2. Кваліфікаційні вимоги до професійної діяльності педагогічних працівників // Збірник матеріалів за результатами дослідження / за заг. ред. Г. В. Сльникової. Київ-Черкаси, 2010. - 144 с. 3. Сгорова В. В. Розвиток ключових компетентностей науковопедагогічних працівників у системі методичної роботи вищого навчального закладу: дис. ... канд. пед. наук: 13.00 .04 / Єгорова Вероніка В'ячеславівна. - К., 2011. - 288 с. 4. Падалка О. С. Інтенсивні технології навчання / Падалка Олег Семенович // Вища освіта України. - 2002. - № 2. - С. 91-95. 5. Цідило І. М. Вплив ІКТ-компетентності педагога на використання інноваційних технологій у навчальному процесі / Цідило Іван Миколайович // Професійні компетенції та компетентності вчителя: матеріали регіон. наук.-практ. семінару. - Тернопіль : Вид-во ТНПУ ім. В. Гнатюка, 2006. - С. 44-46.

Валентин Златніков

\section{ЕТАПИ НАВЧАННЯ ПРОФЕСІЙНО-ОРІЕНТОВАНОГО АУДІЮВАННЯ АНГЛІЙСЬКОЮ МОВОЮ КУРСАНТІВ ВИЩИХ ВІЙСЬКОВИХ НАВЧАЛЬНИХ ЗАКЛАДІВ}

Златніков В. Г. Етапи навчання професійно-орієнтованого аудіювання англійською мовою курсантів вищих військових навчальних закладів.

Стаття присвячена проблемі навчання курсантів вищих військових навчальних закладів професійно-орієнтованого аудіювання англійською мовою. У статті схарактеризовано основні етапи роботи з аудіотекстами, виокремлено педагогічні умови, які впливають на ефективність навчання аудіювання на кожному із визначених етапів.

Ключові слова: професійно-орієнтоване аудіювання, віськово-спеціальна мовна підготовка, педагогічні умови, уміння професійно-орієнтованого аудіювання, комплекс вправ. 